\title{
DESKRIPSI KOMPETENSI GURU SMP MATA PELAJARAN MATEMATIKA DAN IPA
}

\author{
Titin \\ Pendidikan Biologi, FKIP Universitas Tanjungpura \\ titinbasuki@rocketmail.com
}

\begin{abstract}
This research aimed to describe the competency of junior high school teachers of Mathematics and Science subjects. This research uses descriptive method with the survey method. The data source in this research is junior high school teachers of Mathematics and Science subjects which are incorporated in MGMP Sub Rayon 03 Samalantan, the number of teacher is 20. The data were collected through questionnaires. To find out the description of the competence of teachers it used descriptive analysis by using percentage. The result showed an overall competence of teachers are in a good category. The sequentially percentage of the competency of teachers are pedagogic (72.25\%), professional competence (83.00\%), personal competence (85.00\%) and social competence (77\%).
\end{abstract}

Key word: Competence, Junior High School Teachers.

\begin{abstract}
Peningkatan kemampuan guru dalam pelaksanaan proses belajar mengajar merupakan bagaian dari usaha peningkatan mutu pendidikan, dimana guru mempunyai peranan yang sangat penting yaitu sebagai perencana dan pelaksana sesuai dengan tingkat dan perkembangan peserta didik melalui penguasaan didaktik dan metodik.
\end{abstract}

Seiring dengan fenomena tersebut di atas, pembangunan pendidikan yang lebih berkualitas telah dilaksanakan melalui berbagai upaya seperti, pengembangan dan perbaikan kurikulum, pemenuhan sarana dan prasarana pendidikan, sistem evaluasi, pengembangan bahan ajar, pelatihan guru dan tenaga pendidik, dan usaha lainnya.

Guru adalah pendidik profesional dengan tugas utama mendidik, mengajar, membimbing, mengarahkan, melatih, menilai, dan mengevaluasi peserta didik. Untuk meningkatkan kualitas pembelajaran, guru hendaknya memiliki kemampuan dalam menguasai bahan pembelajaran, mengelola kelas, menggunakan media dan sumber pembelajaran, serta menilai prestasi belajar siswa.

Hal ini sejalan dengan Undang-Undang Nomor 14 Tahun 2005 Tentang guru dan dosen pasal 10 Ayat 1 menyatakan bahwa kompetensi yang harus dimiliki oleh guru meliputi kompetensi pedagogik, kompetensi kepribadian, kompetensi sosial dan kompetensi profesional.

Kompetensi

adalah

seperangkat pengetahuan, keterampilan dan perilaku yang harus dimiliki, dihayati, dan dikuasai oleh guru atau dosen dalam melaksanakan tugas kerpofesionalan. Menurut Undang-undang No.14 tahun 2005 tentang Guru Dan Dosen pasal 10 ayat (1) empat kompetensi yang harus 
dimiliki guru sebagai pendidik, diantaranya :

1. Kompetensi Pedagogik, yaitu: kemampuan mengelola pembelajaran peserta didik yang meliputi pemahaman terhadap peserta didik, perancangan dan pelaksanaan pembelajaran, evaluasi hasil belajar, dan pengembangan peserta didik untuk mengaktualisasikan berbagai potensi yang dimilikinya.

2. Kompetensi Kepribadian yaitu: kepribadian pendidik yang mantap, stabil, dewasa, arif, dan berwibawa, menjadi teladan bagi peserta didik, dan berakhlak mulia.

3. Kompetensi Profesional, yaitu: kemampuan pendidik dalam penguasaan materi pembelajaran secara luas dan mendalam yang memungkinkannya membimbing peserta didik memperoleh kompetensi yang ditetapkan.

4. Kompetensi Sosial, yaitu: kemampuan pendidik berkomunikasi dan berinteraksi secara efektif dengan peserta didik, sesama pendidik, tenaga kependidikan, orangtua/wali peserta didik, dan masyarakat.

Empat kompetensi tersebut hendaknya dimiliki oleh pendidik sehingga diharapkan dapat meningkatkan kualitas pembelajaran. Hal ini membawa konsekuensi kepada guru untuk dapat meningkatkan peranan dan kompetensinya. Majid (2011) menjelaskan kompetensi yang dimiliki oleh setiap guru akan menunjukkan kualitas guru dalam mengajar. Kompetensi tersebut akan terwujud dalam bentuk penguasaan pengetahuan dan profesional dalam menjalankan fungsinya sebagai guru.
Upaya yang dilakukan untuk meningkatkan profesionalisme guru dalam rangka pembinaan dan pengembangan dilakukan melalui wadah MGMP (Musyawarah Guru Mata Pelajaran) dilaksanakan dalam satuan-satuan unit pelaksana teknis (UPT) masing-masing kecamatan / kabupaten. Salah satu MGMP (Musyawarah Guru Mata Pelajaran) dilaksanakan oleh guru-guru mata pelajaran Matematika dan Ilmu Pengetahuan Alam Sekolah Menengah Pertama yang berada di Sub Rayon 03 Samalantan Kabupaten Bengkayang, Kalimantan Barat.

Kelompok MGMP IPA dan Matematika SMP Sub Rayon 03 Samalantan ini terdiri atas gabungan dari tiga kecamatan berbeda yaitu kecamatan Samalantan, Lembah Bawang, dan Monterado. Kecamatan Samalantan terletak $40 \mathrm{Km}$ dari kota kabupaten Bengkayang. Perjalanan menuju kecamatan Samalantan ditempuh melalui jalur darat. Samalantan berbatasan dengan kecamatan Lembah Bawang di sebelah utara, kabupaten Landak di sebelah selatan, kecamatan Sungai Betung di sebelah timur dan kecamatan Monterado di sebelah barat.

Sekolah - sekolah yang bergabung dalam kelompok MGMP (Musyawarah Guru Mata Pelajaran) IPA dan Matematika Sub Rayon 03 Samalantan ini terdiri atas 14 (empat belas) sekolah, yaitu SMP Negeri 01 Samalantan, SMP Negeri 02 Samalantan, SMP Negeri 03 Samalantan, SMP Negeri 04 Samalantan, SMP Negeri 05 Samalantan, SMP PGRI 1 Nekbare, SMP Negeri 01 Lembah Bawang, SMP Negeri 2 Lembah Bawang, SMP 
Dwi Darma Aping, SMP Negeri 01

Monterado, SMP Negeri 02 Monterado, SMP Negeri 03 Monterado, SMP PGRI Pakkucing, SMP Pelita Sangkinahu.

$$
\text { Kegiatan }
$$

MGMP

(Musyawarah Guru Mata Pelajaran) yang telah dilaksanakan di Sub Rayon 03 Samalantan, selama ini memegang peranan penting sebagai wadah kegiatan pengembangan diri karena di dalam kegiatan MGMP (Musyawarah Guru Mata Pelajaran) terdapat pelatihan dan kegiatan kolektif guru. Pelaksanaan kegiatan MGMP (Musyawarah Guru Mata Pelajaran) berjalan menggunakan berbagai strategi seperti ceramah dan tanya jawab, diskusi dan workshop. Kegiatan- kegiatan yang telah dilakukan juga menjadi pendorong guru-guru termotivasi mengikuti kegiatan MGMP (Musyawarah Guru Mata Pelajaran). Kegiatan MGMP (Musyawarah Guru Mata Pelajaran) ini telah dilakukan secara rutin oleh kelompok guru-guru IPA dan Matematika di Samalantan. Dari hasil wawancara dengan beberapa guru diperoleh informasi guru-guru sangat antusias mengikuti semua kegiatan dalam MGMP (Musyawarah Guru Mata Pelajaran) karena berdampak pada meningkatnya pengetahuan dan keterampilan yang dimiliki guru.

Berdasarkan uraian di atas, peneliti tertarik untuk memperoleh informasi jenis-jenis kompetensi yang dimiliki oleh kelompok guru IPA dan Matematika yang tergabung dalam MGMP (Musyawarah Guru Mata Pelajaran) IPA dan Matematika SMP Sub Rayon 03 Samalantan.

\section{Metode}

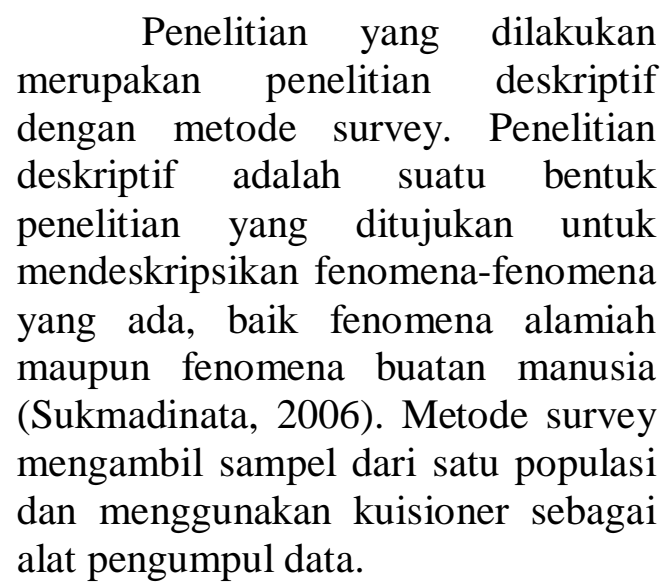

Penelitian ini bertujuan untuk mendapatkan informasi tentang jenisjenis kompetensi yang dimiliki oleh guru IPA dan Matematika SMP yang tergabung dalam MGMP (Musyawarah Guru Mata Pelajaran) Sub Rayon 03 Samalantan.

Waktu penelitian adalah bulan September tahun 2014. Pengambilan sampel penelitian dilakukan secara purposive sampling yakni guru-guru yang mengikuti kegiatan Ipteks Bagi Masyarakat Kelompok Musyawarah Guru Mata Pelajaran (MGMP) IPA dan Matematika SMP Sub Rayon 03 Samalantan Kabupaten Bengkayang. Jumlah sampel penelitian sebanyak 20 orang guru yang tergabung dalam MGMP IPA dan Matematika SMP Sub Rayon 03 Samalantan.

Pengambilan data dilakukan dengan menggunakan angket yang diberikan kepada guru. Menurut Riduwan (2006: 35), angket adalah daftar pertanyaan yang diberikan kepada orang lain bersedia memberikan respon (responden) sesuai permintaan pengguna. Tujuan penyebaran angket ialah mencari informasi yang lengkap mengenai suatu masalah dan responden tanpa merasa khawatir bila responden memberikan jawaban yang tidak 
sesuai dengan kenyataan dalam pengisian daftar pertanyaan. Di samping itu, responden mengetahui informasi tertentu yang diminta..

Penelitian ini menggunakan angket skala Likert dengan menyajikan 20 pernyataan dengan 5 pilihan jawaban. Adapun penilaian untuk masing-masing pilihan jawaban adalah sebagai berikut:

$1=$ Tidak pernah

$2=$ jarang

$3=$ kadang-kadang

$4=$ sering

$5=$ selalu

Data yang telah dikumpulkan selanjutnya dilakukan pengolahan dan dianalisis dengan menggunakan analisis data kuantitatif. Analisis data kuantitatif digunakan untuk menganalisis data skor hasil angket guru melalui metoda statistik. Pengolahan data untuk mengetahui kompetensi guru dilakukan dengan langkah-langkah sebagai berikut:

a. Menyatakan skor dalam bentuk persentase dengan rumus:

$$
N P=\frac{R}{S M} \times 100 \%
$$

Keterangan:

$\mathrm{NP}=$ Persentase kompetensi

$\mathrm{R}=$ Skor yang diperoleh
$\mathrm{SM}=$ Skor maksimum (Purwanto, 1991).

b. Menafsirkan persentase dengan kriteria:

$87 \%$ - 100\% Sangat Baik

$70 \%-86 \%$ Baik

$53 \%-69 \%$ Cukup

$36 \%-52 \%$ Kurang

$\leq 36 \% \quad$ Kurang Sekali

(Modifikasi Purwanto, 1991).

\section{Hasil dan Pembahasan}

Penelitian dilakukan dengan memberikan angket kepada guru-guru yang tergabung dalam MGMP (Musyawarah Guru Mata Pelajaran) IPA dan Matematika SMP Sub Rayon 03 Samalantan sebanyak 20 pernyataan. Penelitian ini bertujuan untuk mengetahui jenis-jenis kompetensi yang dimiliki oleh guruguru yang tergabung dalam MGMP (Musyawarah Guru Mata Pelajaran) IPA dan Matematika SMP Sub Rayon 03 Samalantan

Kompetensi guru yang ingin dideskripsikan mencakup kompetensi pedagogik, kompetensi profesional, kompetensi kepribadian dan kompetensi sosial. Adapun rekapitulasi hasil yang diperoleh untuk setiap item pernyataan kompetensi guru tersebut disajikan pada tabel 1 dibawah ini.

Tabel 1. Persentase Kompetensi Guru.

\begin{tabular}{|c|c|c|c|}
\hline No & Indikator & $\begin{array}{l}\text { Total } \\
\text { Skor }\end{array}$ & Persentase $(\%)$ \\
\hline \multicolumn{4}{|c|}{ KOMPETENSI PEDAGOGIK } \\
\hline 1 & $\begin{array}{l}\text { Memiliki keinginan untuk mengetahui latar } \\
\text { belakang pribadi peserta didik }\end{array}$ & 75 & 75 \\
\hline 2 & $\begin{array}{l}\text { Berusaha membantu memecahkan problem- } \\
\text { problem yang dihadapi peserta didik }\end{array}$ & 75 & 75 \\
\hline 3 & $\begin{array}{l}\text { Ikut serta mengembangkan kurikulum yang } \\
\text { disesuikan dengan kondisi spesifik lingkungan } \\
\text { sekolah }\end{array}$ & 73 & 73 \\
\hline 4 & Mampu untuk memilih metode/strategi & 71 & 71 \\
\hline
\end{tabular}




\begin{tabular}{|c|c|c|c|}
\hline No & Indikator & $\begin{array}{l}\text { Total } \\
\text { Skor }\end{array}$ & Persentase $(\%)$ \\
\hline 5 & $\begin{array}{l}\text { pembelajaran yang tepat dalam pembelajaran } \\
\text { Mempu menciptakan situasi belajar bagi anak } \\
\text { yang kreatif, aktif, dan menyenangkan }\end{array}$ & 70 & 70 \\
\hline 6 & $\begin{array}{l}\text { Mempu menggunakan sumber } \\
\text { belajar/media/alat peraga pembelajaran }\end{array}$ & 67 & 67 \\
\hline 7 & $\begin{array}{l}\text { Memiliki kemampuan untuk mengevaluasi } \\
\text { pembelajaran dengan merencanakan penilaian } \\
\text { yang tepat, melakukan pengukuran dengan } \\
\text { benar }\end{array}$ & 76 & 76 \\
\hline \multirow[t]{2}{*}{8} & Mampu mengalokasikan waktu & 71 & 71 \\
\hline & & Total skor & 72.25 \\
\hline \multicolumn{4}{|c|}{ KOMPETENSI KEPRIBADIAN } \\
\hline 9 & Memiliki kewibawaan & 85 & 85 \\
\hline 10 & $\begin{array}{l}\text { Memiliki sifat keterbukaan baik pada rekan } \\
\text { kerja maupun peserta didik }\end{array}$ & 87 & 87 \\
\hline 11 & Memiliki tanggung jawab & 90 & 90 \\
\hline \multirow[t]{2}{*}{12} & $\begin{array}{l}\text { Mampu menjadi panutan dan teladan bagi } \\
\text { peserta didik }\end{array}$ & 80 & 80 \\
\hline & & Total skor & 85.50 \\
\hline \multicolumn{4}{|c|}{ KOMPETENSI PROFESIONAL } \\
\hline 13 & $\begin{array}{l}\text { Memiliki kemampuan penguasaan materi } \\
\text { pelajaran }\end{array}$ & 90 & 90 \\
\hline 14 & $\begin{array}{l}\text { Memiliki kemampuan untuk mengaitkan materi } \\
\text { yang diajarkan dengan materi pada bidang } \\
\text { yang lain }\end{array}$ & 77 & 77 \\
\hline 15 & $\begin{array}{l}\text { Memiliki kemampuan penelitian dan } \\
\text { penyusunan karya ilmiah }\end{array}$ & 50 & 50 \\
\hline \multirow[t]{2}{*}{16} & Memiliki kemampuan pengembangan profesi & 54 & 54 \\
\hline & & Total skor & 83.50 \\
\hline \multicolumn{4}{|c|}{ KOMPETENSI SOSIAL } \\
\hline 17 & $\begin{array}{l}\text { Memiliki kemampuan berinteraksi dengan } \\
\text { peserta didik }\end{array}$ & 87 & 87 \\
\hline 18 & $\begin{array}{l}\text { Memiliki kemampuan berinteraksi dengan } \\
\text { sesama guru }\end{array}$ & 89 & 89 \\
\hline 19 & $\begin{array}{l}\text { Memiliki kemampuan berinteraksi dengan } \\
\text { kepala sekolah }\end{array}$ & 88 & 88 \\
\hline 20 & $\begin{array}{l}\text { Memiliki kemampuan berinteraksi dengan } \\
\text { pegawai Tata Usaha }\end{array}$ & 89 & 89 \\
\hline \multirow[t]{2}{*}{21} & $\begin{array}{l}\text { Memiliki kemampuan berinteraksi dengan } \\
\text { anggota masyarakat }\end{array}$ & 82 & 82 \\
\hline & & Total skor & 77.00 \\
\hline
\end{tabular}

Ket: Skor maksimal $=100$

Dari rekapitulasi angket kompetensi profesional, sosial, dan diperoleh hasil bahwa persentase pedagogik. Adapun keseluruhan kompetensi kepribadian yang dimiliki kompetensi guru yang diperoleh oleh guru memberikan pengaruh yang disajikan pada Gambar 1. paling tinggi dibandingkan persentase 


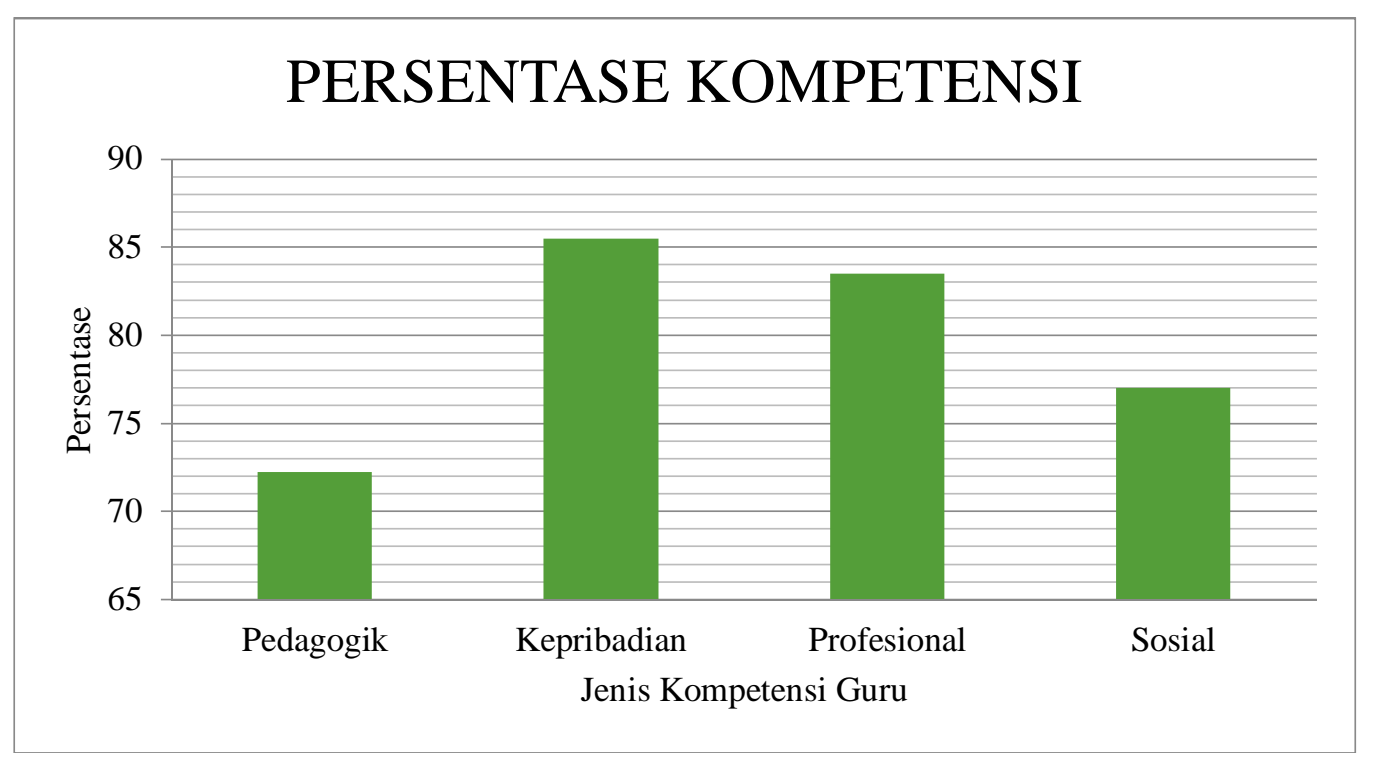

Gambar1: Persentase Jenis Kompetensi Guru.

Kompetensi kepribadian adalah kemampuan seseorang yang diwujudkan dalam kepribadian yang mantap, berwibawa, stabil, dewasa dan berakhlaq mulia serta mampu sebagai teladan bagi peserta didik. Kompetensi kepribadian dalam penelitian ini memiliki persentase tertinggi terhadap kompetensi guru secara keseluruhan. Sebagian besar guru menyatakan telah memiliki kewibawaan, memiliki sifat keterbukaan baik pada rekan kerja maupun peserta didik, memiliki tanggung jawab dan berharap dapat menjadi panutan dan teladan bagi peserta didik.

Kompetensi ini menjadi sangat penting karena tolak ukur seorang guru adalah menjadi contoh atau teladan bagi siswanya. Hal ini sejalan dengan pernyataan Montori (2013) bahwa tolak ukur keberhasilan guru dalam menghadapi tantangan di era tanpa batas ini tidak cukup hanya bermodalkan hardskill (kemampuan keahlian, pelatihan, atau pengalaman), tetapi juga harus bermodalkan softskill, yaitu kemampuan mengelola diri sendiri dan membangun hubungan harmonis dengan siswa dan seluruh stakeholders pendidikan. Untuk itu guru harus memiliki karakter, sikap dan tindakan yang baik dihadapan siswa/ siswinya maupun bagi orang lain.

Pada kompetensi profesional diketahui bahwa guru memiliki kemampuan yang baik dalam menguasai materi. Selain itu dalam proses pembelajaran guru juga memiliki kemampuan untuk mengaitkan materi yang diajarkan dengan materi pada bidang yang lain. Hal ini didukung oleh Subandi dan Isnandar (2010: 1) dimana salah satu cara untuk meningkatkan kualitas pendidikan adalah peningkatan kualitas guru, karena guru memiliki peranan sentral dalam proses pembelajaran di sekolah. Guru sebagai motivator dan mediator bagi siswa untuk dapat belajar secara 
efektif dan efisien. Karena itu guru harus berperan mendorong siswa untuk belajar. Dalam hal ini guru dituntut menjadi profesional dalam penguasaan materi dan pembelajaran.

Subandi dan Isnandar (2010:

1) juga menyatakan bahwa perlu adanya upaya keras untuk bisa mengubah perilaku guru dari penyampai atau pemberi pengetahuan menjadi pembangkit proses belajar. Salah satu upaya yang dapat dilakukan untuk mengubah paradigma tersebut adalah mengadakan pelatihan guru (inservice training). Guru-guru yang sudah memiliki pengalaman mengajar cukup lama dan memegang paradigma penyampai pengetahuan harus diubah pola pikirnya menjadi pembangkit belajar untuk siswanya. Guru dituntut bertindak lebih aktif, kreatif, dan bertanggungjawab. Guru harus memandang siswa sebagai subjek belajar dalam proses pembelajaran. Berarti guru harus memfasilitasi siswa untuk mudah mengonstruksi pengetahuan. Dalam hal ini, guru harus memiliki kemampuan untuk mengemas materi pelajaran supaya menjadi bermakna bagi siswa, menciptakan situasi kelas yang mendorong siswa untuk berpikir dan berinteraksi, serta menciptakan situasi yang kondusif dan menyenangkan bagi siswa untuk belajar.

Proses pembelajaran merupakan interaksi antara guru dan peserta didik dalam penyampaian suatu materi atau ilmu. Guru juga memegang peran yang penting dalam proses pembelajaran yang berpengaruh terhadap hasil yang akan dicapai dari proses pembelajaran tersebut. Berdasarkan PP Nomor 16 tahun 2009 bahwa akan dilaksanakan Kinerja Guru (PKG) yang nilainya 90\% dari hasil kegiatan pembelajaran guru, guru dituntut untuk mampu menerapkan berbagai strategi di dalam kelas (Grafura, 2012: 10).

Sejalan dengan hal tersebut kompetensi profesional lainnya yang dituntut oleh pemerintah adalah dengan diberlakukan Permenpan dan Reformasi Birokrasi Nomor 16 Tahun 2009 tertanggal 10 Nopember 2009, tentang Jabatan Fungsional Guru dan Angka Kreditnya mensyaratkan Publikasi ilmiah/ karya inovatif (karya tulis ilmiah, membuat alat peraga, alat pelajaran, karya teknologi/seni) menjadi salah satu syarat yang harus dipenuhi dalam pengusulan kenaikan pangkat dan golongan mulai dari golongan III a ke III b hingga golongan IVe mulai 1 Januari 2013.

Namun disisi lain kemampuan guru dalam melakukan penelitian, penyusunan karya ilmiah dan kemampuan dalam mengembangkan profesi lainnya masih dirasakan kurang oleh guru-guru atau dengan kata lain berada pada kategori rendah. Hal ini diketahui saat kegiatan Ipteks Bagi Masyarakat (IbM) Kelompok Musyawarah Guru Mata Pelajaran (MGMP) IPA dan Matematika SMP Sub Rayon 03 Samalantan Kabupaten Bengkayang, guru yang tergabung didalam MGMP Sub Rayon 03 Samalantan menyatakan bahwa salah satu kendala dalam hal kenaikan pangkat adalah dikarenakan kesulitan dalam melakukan penelitian dan publikasi ilmiah serta kurangnya pengetahuan dan informasi terkini menyebabkan beberapa guru kesulitan dalam melakukan pengembangan diri. 
Pada kompetensi sosial, didapatkan hasil bahwa guru-guru yang tergabung dalam kelompok MGMP (Musyawarah Guru Mata Pelajaran) Sub Rayon 03 Samalantan memiliki kemampuan dalam berinteraksi baik dengan peserta didik, sesama guru, kepala sekolah, pegawai tata usaha dan stakeholder atau anggota masyarakat lainnya. Kegiatan MGMP (Musyawarah Guru Mata Pelajaran) Sub Rayon 03 Samalantan menjadi pertemuan rutin untuk melakukan diskusi berbagai hal yang terkait dengan proses pembelajaran, pembimbingan maupun pembinaan langsung dari pihak yang kompeten dibidangnya, serta melakukan pelatihan, seminar maupun workshop dengan tujuan akhirnya adalah meningkatkan kualitas pendidikan.

$\begin{array}{lr}\text { Kompetensi } & \text { pedagogik } \\ \text { memiliki persentase } & \text { terendah } \\ \text { dibandingkan kompetensi lainnya. } & \text { lain } \\ \text { Meskipun demikian kompetensi }\end{array}$ pedagogik yang dimiliki oleh guruguru tersebut masih berada pada kategori baik. Kaitannya dengan kompetensi pedagogik, guru-guru yang tergabung dalam kelompok MGMP (Musyawarah Guru Mata Pelajaran) Sub Rayon 03 Samalantan menyatakan memiliki keinginan untuk mengetahui latar belakang pribadi peserta didik serta berusaha membantu memecahkan problemproblem yang dihadapi peserta didik.

Latar belakang sosial ekonomi yang berbeda yang dimiliki oleh peserta didik turut mempengaruhi hasil belajar yang diperolehnya. Hal yang demikian menuntut guru untuk dapat mengetahui permasalahanpermasalahan yang dimiliki oleh peserta didik bahkan turut membantu dalam mengatasi permasalahan tersebut. Sebagai contoh ada beberapa peserta didik yang memiliki prestasi akademik baik namun kesulitan dalam perekonomian difasilitasi untuk dapat memperoleh beasiswa.

Selain itu dalam pelaksanaan pembelajaran, guru juga turut serta dalam mengembangkan kurikulum yang disesuaikan dengan kondisi spesifik lingkungan sekolah. Guruguru yang tergabung didalam MGMP (Musyawarah Guru Mata Pelajaran) Sub Rayon 03 Samalantan juga menyatakan memiliki kemampuan untuk memilih metode/strategi pembelajaran yang tepat dalam pembelajaran dan menggunakan sumber belajar/ media/ alat peraga yang sesuai dalam pembelajaran.

Variasi pola interaksi guru dengan murid dalam kegiatan belajar mengajar juga telah dilakukan, mulai dari kegiatan yang didominasi oleh guru sampai kegiatan sendiri yang dilakukan anak. Penggunaan variasi pola interaksi dimaksudkan agar tidak menimbulkan kebosanan, kejemuan, serta untuk menghidupkan suasana kelas demi keberhasilan siswa dalam mencapai tujuan.

Menurut Syaefudin (2009) jenis-jenis pola interaksi pembelajaran yakni: 1) pola gurumurid, yakni komunikasi sebagai aksi (satu arah), 2) pola guru-murid-guru, yakni ada balikan (feedback) bagi guru, tidak ada interaksi antarsiswa (komunikasi sebagai interaksi), 3) pola guru-murid-murid, yakni ada balikan bagi guru, siswa saling belajar satu sama lain, 4) pola guru-murid, murid-guru, murid-murid. Interaksi optimal antara guru dengan murid dan antara murid dengan murid (komunikasi sebagai transaksi 
(multiarah), 5) pola melingkar, dimana setiap siswa mendapat giliran untuk mengemukakan sambutan atau jawaban, tidak diperkenankan berbicara dua kali apabila setiap siswa belum mendapat giliran.

Selain itu juga variasi dalam penggunaan media dan alat pembelajaran sudah dilakukan oleh guru dalam melaksanakan pembelajaran. Adapun variasi yang telah dilakukan antara lain variasi alat atau bahan yang dapat dilihat (visual aids), variasi alat atau bahan yang dapat didengar (auditif aids), variasi alat atau bahan yang dapat diraba (motorik), dan variasi alat atau bahan yang dapat didengar, dilihat dan diraba (audio visual aids).

Sejalan dengan pendapat Trianto (2009) dalam proses pembelajaran seorang guru harus bijaksana dalam menentukan suatu model yang sesuai sehingga dapat menciptakan situasi dan kondisi kelas yang kondusif agar proses belajar mengajar dapat berlangsung sesuai dengan tujuan yang diharapkan. Hal ini tentunya akan sangat mendukung perwujudan PP Nomor 16 tahun 2009 dengan akan dilaksanakan Kinerja Guru (PKG), guru dituntut untuk mampu menerapkan berbagai strategi di dalam kelas (Grafura, 2012: 10). Selain itu guru juga mampu menciptakan situasi belajar bagi anak yang kreatif, aktif dan menyenangkan.

Keberhasilan seorang guru dalam mengajar tidak hanya ditentukan oleh faktor-faktor yang berhubungan dengan proses pembelajaran saja, melainkan juga ditentukan oleh keterampilan pengelolaan kelas yang dikuasainya. Keterampilan mengelola kelas adalah keterampilan guru untuk menciptakan dan memelihara kondisi belajar yang optimal dan keterampilan untuk mengembalikan kondisi belajar yang optimal.

Terkait dengan kompetesi pedagogik, diketahui saat kegiatan Ipteks Bagi Masyarakat (IbM) Kelompok Musyawarah Guru Mata Pelajaran (MGMP) IPA dan Matematika SMP Sub Rayon 03 Samalantan Kabupaten Bengkayang beberapa guru masih merasa kesulitan dalam melakukan evaluasi pembelajaran dengan menggunakan kurikulum 2013 yakni merencanakan penilaian yang tepat, dan melakukan pengukuran dengan benar. Beberapa guru menyatakan masih sulit melakukan penilaian, hal ini dikarenakan guru belum terlatih dan terampil membuat instrumen penilaiannya.

Kurikulum dirancang untuk memberikan pengalaman belajar seluas-luasnya bagi peserta didik untuk mengembangkan sikap, keterampilan dan pengetahuan yang diperlukan untuk membangun kemampuan tersebut (Kementerian Pendidikan dan Kebudayaan: 2012). Dalam penerapan kurikulum 2013 ada tiga penilaian yang harus dilakukan oleh guru yaitu penilaian pengetahuan, sikap dan ketrampilan. Penilaian keterampilan merupakan salah satu titik berat dalam penilaian kurikulum 2013, karena sejauh ini penilaian ini termasuk yang jarang dilakukan oleh guru-guru. Pada kurikulum sebelumnya guru lebih dominan menggunakan penilaian pengetahuan (kognitif). 


\section{Simpulan dan Saran}

Kesimpulan yang diperoleh dari hasil penelitian adalah deskripsi kompetensi guru-guru yang tergabung dalam MGMP Matematika dan IPA Sub Rayon 03 Samalantan secara berurutan dilihat dari hasil penelitian yaitu kompetensi pedagogik berada pada kategori baik (72.25 \%), kompetensi kepribadian berada pada kategori baik $(85.00 \%)$, kompetensi profesional berada pada kategori baik (83.00 \%), dan kompetensi sosial berada pada kategori baik (77.00\%).

Perlu memfasilitasi guru dengan berbagai bentuk kegiatan guna peningkatan kompetensi profesional guru khususnya berkaitan dengan kemampuan guru dalam melakukan penelitian, penyusunan karya ilmiah dan kemampuan dalam mengembangkan profesi danpeningkatan kompetensi pedagogik khususnya dalam hal merencanakan penilaian yang tepat, dan melakukan pengukuran dengan benar. Perlu penelitian lanjutan guna menggali konten materi yang dikuasai oleh guru SMP yang tergabung dalam kelompok MGMP Sub Rayon 03 Samalantan.

\section{Daftar Pustaka}

Arikunto, Suharsimi. 1990. Metode Penelitian. Jakarta: Angkasa

Grafura, Lubis. 2012. Metode dan Starategi Pembelajaran Yang Unik. Jogjakarta: Ar-Ruzz Media.

Kementerian Pendidikan dan Kebudayaan. 2012. Dokumen Kurikulum 2013. Jakarta: -
Majid, Abdul. 2011. Perencanaan Pembelajaran

(Mengembangkan Standar Kompetensi Guru). Jakarta: Rosda

Montori, Soleman. 2013. Guru: Teladan, Tanggung Jawab, Kreativitas (Refleksi Hari Pendidikan Nasional). http://www.antarasulut.com.

Diakses pada tanggal 10 Oktober 2014

Purwanto, M.N. 1991. PrinsipPrinsip Dan Teknik Evaluasi Pengajaran. Bandung: PT Remaja Rosdakarya

Sukmadinata, Nana Syaodih. 2006. Metode Penelitian Pendidikan. Bandung: Remaja Rosdakarya

Riduwan. (2006). Belajar Mudah Untuk Guru, Karyawan, dan Peneliti Pemula. Bandung: Alfabeta

Subandi dan Isnandar. 2010. Meningkatkan Profesionalisme Guru SD Melalui TEQIP. Jurnal J-TEQIP, Tahun 1, Nomor 1, November 2010.

Syaefudin, S. 2009. Pengembangan Profesi Guru. Bandung: CV. Alfabeta.

Trianto. 2009. Mendesain Model Pembelajaran InovatifProgresif. Jakarta : Kencana Prenada Media Group. 